\title{
Whose 'Reality'? Discourses and Hydropolitics along the Yarmouk River
}

\author{
Hussam Hussein $^{12}$ \\ ${ }^{1}$ Water Security Research Centre and Tyndall Centre for Climate Change Research, School of \\ International Development, University of East Anglia (UEA), Norwich, UK - h.hussein@uea.ac.uk \\ ${ }^{2}$ Issam Fares Institute for Public Policy and International Affairs, American University of Beirut \\ (AUB), Beirut, Lebanon
}

FUNDING: My gratitude is due to the Council for British Research in the Levant (CBRL) who granted me a travel award to conduct data collection for this research.

\begin{abstract}
This article investigates Jordanian and Syrian hydropolitical discourses around the bilateral relations along the Yarmouk River, with a focus on the decreased flow of the Yarmouk River reaching the Wahda Dam. The article examines the bilateral agreements, the hydropolitical discourses they generate, and the competing solutions they open. By situating the analysis in the broader Jordanian-Syrian relations and considerations of power asymmetries, the empirical case study of the Yarmouk River Basin contributes to both hydropolitics and environmental discourse theory literatures.
\end{abstract}

\section{Keywords}

Hydropolitics; Yarmouk River; Jordan; Syria; Discourses; Water politics.

\author{
Abbreviations \\ EDT $=$ Environmental discourse theory \\ FAO $=$ Food Agricultural Organisation \\ $\mathrm{FHH}=$ Framework of Hydro-Hegemony \\ LWRG $=$ London Water Research Group \\ $\mathrm{MCM}=$ Million cubic metres \\ MFA $=$ Ministry of Foreign Affairs \\ MWI $=$ Ministry of Water and Irrigation \\ NWC $=$ National Water Carrier \\ $\mathrm{TWG}=$ Transboundary Water Governance \\ UN ESCWA = United Nations Economic and Social Commission for Western Asia
}

This article analyses the bilateral agreements concerned with the transboundary water governance (TWG) of the Yarmouk River, with a specific focus on Jordanian-Syrian hydropolitical relations. By demonstrating why the agreement, which was first signed in 1953, was renegotiated in 1987, this article sheds light on some of the ambiguities behind these treaties that are at the heart of the water controversy - ambiguities that contribute to generate the hydropolitical discourses presented in this article. Policy solutions pursued by the Jordanian government have not been implemented to date, including action against what Jordanian officials perceive as frequent Syrian 
violations of the bilateral treaty on the Yarmouk. This article adopts a discourse theory framework to explore why the Jordanian solutions are not successfully implemented. In order to understand water allocations among the riparian states in the case of TWG, power dynamics and inter-sectoral interests within the basin need to be considered, particularly when they contribute to the shaping of a country's foreign policy. This article takes discourse to mean a 'shared way of apprehending the world' (Dryzek, 1997: 8), which redefines and reinforces what is perceived to be the 'truth' or 'reality' (Foucault, 1980).

A discourse analysis of the hydropolitical relations between Jordan and Syria is still missing. Hussein and Grandi (2015) have recently analysed the Jordanian - Syrian hydropolitical relations on the Yarmouk in the context of the broader geopolitical context. They propose a 'problemshed' approach that advocates the consideration of 'variables external to the water sector' to 'enable a better understanding of often hidden dynamics that play a core role in shaping water policies and hydropolitical relationships' (Hussein and Grandi 2017: 4 - online version) and to explain why change has happened over time. They do not, however, consider the role of different hydropolitical discourses in shaping Jordanian-Syrian relations and in constructing hydropolitical realities. Furthermore, studies researching water politics in the Jordan River Basin tend to overlook its largest tributary: the Yarmouk River (Figure 1). Their focus has mainly been on hydraulic projects designed to increase the exploitation of the water resources of the river and in the riparian countries. 


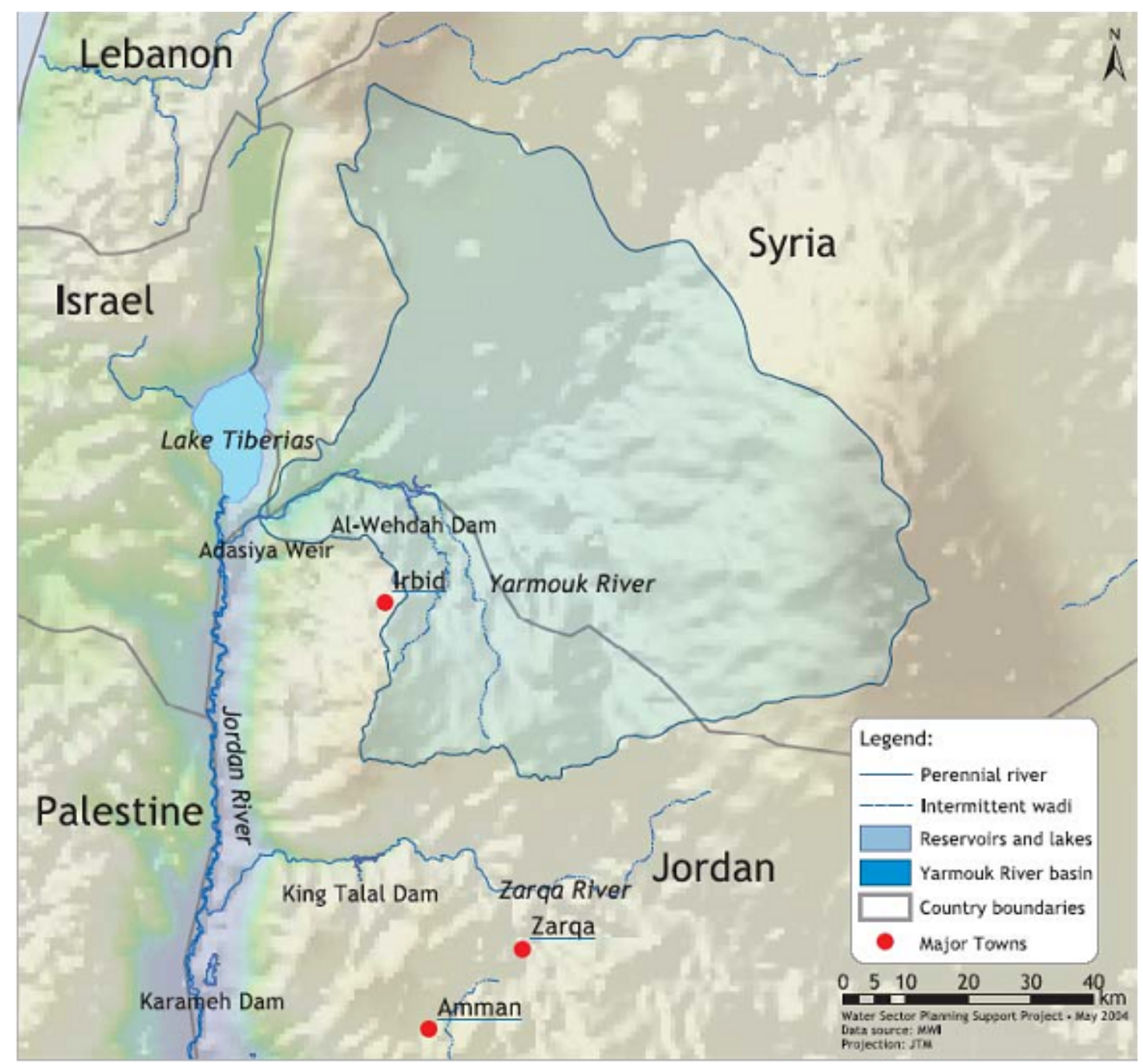

Figure 1: The Yarmouk River Basin (MWI 2011)

Data utilised in this article was collected during fieldwork that took place over ten months in Amman, Jordan, between 2014 and 2015. In total, 106, mostly face to face, semi-structured interviews were conducted with policy-makers, governmental officials, academics, and journalists. The Syrian perspective has been captured through semi-structured interviews with Syrian diplomats, academics, and key informants interviewed in Amman, at international conferences, and via Skype. In addition, official documents, reports, and statistical hydrological data were consulted alongside field observation. Although my aim in this article is to address both the Jordanian and the Syrian sides, I focus more on the Jordanian side due to data availability and accessibility at the time of research. For this reason, a limitation of this article is that while both Jordanian and the Syrian hydropolitical discourses are presented, I am able to provide the responses of Jordanian officials to the Syrian discourses identified, but not the Syrian responses to the Jordanian discourses.

\section{Hydropolitics and Discourse}

The London Water Research Group (LWRG) has developed a conceptual approach to the study of TWG that highlights its political nature. Considering power asymmetries becomes necessary to understand the allocation, planning and management of transboundary water resources. In accordance with the LWRG research, Zeitoun and Warner (2006) have developed the Framework of Hydro-Hegemony (FHH) to 
explain how control over shared water resources is achieved and maintained. The FHH is based on Lukes' definition of power, which he divides into three dimensions (Lukes 1974): overt or material power; covert or bargaining power; and structural or ideational power. The first dimension considers visible power, such as military and economic power resources. The second dimension of power is the ability to have control of the political agenda and to decide what can and cannot be discussed. This includes skills, strategies, and tactics adopted to exert more power over negotiations and influence political agendas. The third dimension is ideational power, which is the power of shaping perceptions and influencing actors' understandings of the possibilities of change (Lukes 1974).

Informed by a Foucauldian theoretical approach and by environmental discourse theory (EDT), this article focuses in particular on the third dimension, ideational power, and examines the role of hydropolitical discourses in shaping the 'reality' of the politics of the Yarmouk River. For Foucault 'power is diffused rather than concentrated, embodied and enacted rather than possessed, discursive rather than purely coercive, and constitutes agents rather than being deployed by them' (Gaventa 2003: 1). Power is everywhere, not only in discourses but also in daily practices and people's behaviour (Foucault 1991; 1998). Foucault makes a direct link between power, knowledge and discourse, as their interaction contributes to the construction of shared understandings of the social world and of what is perceived to be the 'truth' (Foucault 1980: 131). The 'truth,' Foucault (1980) argues, is continuously reinforced and redefined through discourses, through a constant 'battle for truth' that takes place everywhere and in all spheres of society, including mass media, the educational system, and governmental institutions. Power, therefore, can be considered boundaries that constrain possibilities for action, thus enabling (and disabling) solutions (Hayward 1998).

In line with Foucault, EDT (Hajer 1995; Dryzek 1997) emphasizes the importance of discourse in shaping environmental change and policy-making as it legitimises and sanctions certain solutions and discredits and silences others (Leach and Mearns 1996). Dryzek examines the way discourse interacts with, and how it can play a role in, environmental policy and what he terms 'ecological democracy.' For him, a discourse is 'a shared way of apprehending the world. [...] It enables those who subscribe to it to interpret bits of information and put them together into coherent stories or accounts,' thus legitimising knowledge and justifying specific policies (1997: 8). For EDT, the focus needs to be on dominant discourses of power, which are the mainstream ones, and to which most of the population subscribes to. These discourses are usually sanctioned, in other words supported by persons in power, and are in line with what these persons believe to be politically logical. EDT shows that dominant discourses are important because they are able to open the solutions that are adopted by policy makers. For instance, in the case of Jordan, the governmental institutions sanction the discourse of 'water scarcity due to limited water resources,' driving in this way towards policy solutions that aim at increasing water resources in the country (Hussein 2017a). This discourse is sanctioned in all governmental reports and declarations, but also in conferences, textbooks, media, and even in religious sermons (Hussein 2016: chapter 6; Hussein 2017b). It de-emphasises the other possible causes of water scarcity while maintaining the status quo of current water uses, without undermining the interests of (powerful and influential) groups benefiting from the current water allocation in the country. This sanctioned discourse 
is dominant in Jordan (Hussein 2016). Hajer (1995) contributes to EDT by further presenting the concept of 'discourse alliances,' which shows how different themes or sub-discourses - can contribute to an overall discourse by opening the same solution, even if these themes are not related to each other and are constructed by different actors or groups. In this article, I argue that while at the national level EDT is useful in explaining the role of discourses in opening solutions and how and why these policies are implemented, when it comes to Transboundary Water Governance, EDT needs to be complemented by other theories. In fact, as different riparian countries may have competing interests embedded in different dominant discourses, there needs to be a hydropolitical analysis of power relations of the riparian states, which includes consideration of overall bilateral relations. Hence, this article complements EDT with the use of critical hydropolitics and a consideration of ideational power (Luke 1974), as discussed above.

\section{Hydropolitics of the Yarmouk River}

This section presents a description of the Yarmouk River geography and examines the hydropolitics of the river. In particular, it discusses the TWG, which includes the plans, projects, and agreements about how to manage the shared water resources of the river among the riparian states (see Table 1). The section focuses on JordanianSyrian relations, highlighting why the agreement first signed in 1953 was then renegotiated in 1987. My aim is to show the ambiguities of the arrangements and agreements that form the heart of the hydropolitical controversy.

The Yarmouk River forms part of the borders between Syria and Jordan. To be precise, the official border between the two countries is the river, where it is closer to Jordan than the Hijaz Railroad. The railroad, in its part, becomes the border when it is closer to Jordan than the river. ${ }^{1}$ The Yarmouk, with a historic flow of $468 \mathrm{MCM}$ per annum, is the largest tributary of the Jordan River. ${ }^{2}$ Although the quality of its waters is better than the quality of the Jordan River (it is less polluted and therefore more suitable for agricultural uses), its quantity is decreasing. The Yarmouk River is $57 \mathrm{~km}$ in length, of which $47 \mathrm{~km}$ are in Syrian territory (FAO 2009). ${ }^{3}$ The water from the Yarmouk accounts for $40 \%$ of Jordan's surface water resources. Moreover, it is an important source for the King Abdullah $\mathrm{Canal}^{4}$ used in the Jordan Valley for irrigation purposes (Nortcliff et al. 2011: 406). ${ }^{5}$

\footnotetext{
${ }^{1}$ The Yarmouk River also forms part of the borders between Jordan and Israel.

2 This is in comparison to the Hasbani (springing in Lebanon with historic annual discharge of 157 $\mathrm{MCM}$ ), the Banyas (springing in Syria at $125 \mathrm{MCM}$ per annum), and the Dan (springing inside Israel at $258 \mathrm{MCM}$ per annum).

${ }^{3}$ The five main tributaries of the Yarmouk River in Syria are al-Zaidi, Abu al-Dhahab, al-Harir, alAlan, and al-Raqad (EtanaFiles, 2015: 7). The sixth, al-Shallaleh, is inside Jordan.

${ }^{4}$ The canal also receives water from the other wadis, rivers, and tributaries of the Jordan River (Nortcliff et al. 2011: 406). Built at the beginning of the 1960s, the King Abdullah Canal, known as the East Ghor Main Canal until 1987, is the largest irrigation canal system in Jordan and runs for $110.5 \mathrm{~km}$ in the Jordan Valley close to the foothills and parallel to the Jordan River (FAO 2009).

${ }^{5}$ Water uses in the two countries are very different. In 2011 , for example, the total agricultural water use in Jordan amounted to $58 \%$ of total water uses, around $500 \mathrm{MCM}$ a year. In that same year, the municipal sector used around $37 \%$ of the total water used, almost $350 \mathrm{MCM}$, and the industrial use accounted for 5\%, about $37 \mathrm{MCM}$. It is noteworthy that direct agriculture is responsible for around $3 \%$ of the national GDP (but is magnified by sectors dependent on it, adding up to $27 \%$ of GDP), industry for around 30\%, and services, including tourism, for around 67\% (IFC 2012: 5). In Syria, on the other hand, in 2008 agriculture consumed about $87 \%$ of the water supply, the domestic sector about $9 \%$, and industries about 4\% (Salman and Mualla 2008). Agriculture in Syria played an important role in the
} 
Table 1: Main hydropolitical events on the Yarmouk River

\begin{tabular}{|l|l|}
\hline Event & Year \\
\hline 1953 & $\begin{array}{l}\text { First Jordanian-Syrian agreement on the } \\
\text { Yarmouk River }\end{array}$ \\
\hline 1987 & $\begin{array}{l}\text { Second Jordanian-Syrian agreement on } \\
\text { the Yarmouk River }\end{array}$ \\
\hline 1994 & Peace Treaty between Israel and Jordan \\
\hline $\begin{array}{l}\text { Early 2000s (2003 according to Zoubi } \\
\text { and 2001 according to Rosenberg) }\end{array}$ & $\begin{array}{l}\text { Arrangements between Jordan and Syria } \\
\text { on the constructions of the Wahda Dam }\end{array}$ \\
\hline 2004 & $\begin{array}{l}\text { Beginning of the construction of the } \\
\text { dam }\end{array}$ \\
\hline 2006 & End of construction \\
\hline 2009 & Wahda Dam becomes operational \\
\hline 2011 & Start of the Syrian civil war \\
\hline
\end{tabular}

Source: Author's own compilation

As there are no diplomatic relations between Israel and Syria, there are no basin wide agreements on the Yarmouk River apart from two bilateral agreements (UN-ESCWA 2013; FAO 2009): the Jordanian-Syrian bilateral agreement signed in 1953 and renegotiated in 1987 and the Jordanian-Israeli bilateral treaty signed in $1994^{6}$ (UNESCWA 2013). In the following section, I trace the development of agreements that took place between Jordan and Syria up until the completion of building the dam.

The first agreement (1953) proposed the construction of a dam near Maqarin Railroad station on the border between Jordan and Syria, with a live storage capacity of 300 $\mathrm{MCM}$ and a hydropower generating station at the Jordanian village of Adassiya, with 75\% of the electricity allocated to Syria and 25\% to Jordan (UN-ESCWA 2013: 210211; Haddadin 2009: 421; Hof 1998: 84). However, political relations between the two governments became tense in 1957 due to the so-called Arab Cold War between the promoters of Arab nationalism and pan-Arabism (1957-1967), guided by Egyptian President Abdel Nasser and supported by Syria, and Arab monarchies, that included the Jordanian Hashemites. As a result, the Yarmouk Joint Water Committee did not meet when bilateral relations grew tense due to changing geopolitical alliances (Haddadin 2006: 250). In the decades after 1953, without formal negotiations, the Syrian government reduced the flow of the river downstream by the following actions: expanding the use of upstream springs, increasing the use of groundwater resources feeding the lower springs on the Jordanian side and damming the tributaries to the river (Haddadin 2006: 251).

national economy, particularly due to Syria's approach to food security through food sufficiency. Nevertheless, agriculture in Syria has been strongly criticised for not being efficient, and for its mismanagement of water resources (ARK 2016; Barnes 2009).

${ }^{6}$ According to the 1994 Jordan - Israel Peace Treaty, Israel is entitled to $25 \mathrm{MCM}$ of Yarmouk waters per year: $12 \mathrm{MCM}$ to be received between May 15 - October 15, and $13 \mathrm{MCM}$ during the rest of the year. The balance of the flow at Adassiya is used by Jordan. Additionally, Jordan is entitled to 10 MCM per year in exchange for the water that Israel is allowed to pump from the wadi bed in Wadi Araba. Jordan is also entitled to $50 \mathrm{MCM}$ per year under the clause 'Additional Water' of the Peace Treaty - although it is unclear who is responsible to cover the costs for producing this additional water. In addition, Jordan is allowed to store in Lake Tiberias whatever winter flow Jordan does not divert into its King Abdullah Canal. The amount stored will thus be delivered to Jordan on request (during the dry months). 
In 1985, the visit of King Hussein to Damascus marked the rapprochement between the two countries. Jordan abandoned its separate talks with Israel and apologised for having supported the Muslim Brotherhood movement in Jordan and their Syrian activists in the early 1980s. In the context of this transformative climate, the two governments negotiated a new agreement on the Yarmouk River in 1987. This included the provisions of a smaller dam (the mentioned Wahda or Unity Dam) that would be $95 \mathrm{~m}$ high with a maximum capacity of $200 \mathrm{MCM}$ and a reservoir at Maqarin. The agreement adopted an inter-governmental approach to dispute resolution rather than third-party arbitration (which was the case in the previous 1953 agreement). This seemed to work to Syria's advantage: the treaty recognised the 26 Syrian dams on the Yarmouk River's tributaries inside Syria, upstream from Maqarin site. This means that Jordan could not impound meaningful water floods except after the Syrian dams spilled. Dams usually serve one or more purposes of impounding floodwater for later on-demand use, flood protection, and power generation. In the 1987 agreement, the planned dam was meant to serve both impounding water and power generation, which suggested that the two governments intended to pursue electricity production on top of water supply increase (interview 12 with Jordanian official). While Syria was more interested in the electricity production, Jordan's main goal was to increase its water resources.

The bilateral relations between Syria and Jordan improved in the 1990s, but it was only in the early 2000s that an arrangement, rather than an official 'agreement' (Rosenberg 2006), took place. Former Secretary General at the Jordanian MWI clarified this new 'arrangement' by explaining that, 'in 2003 the height of the dam was reduced to 87 meters and the storage capacity became 110 MCM' (Zoubi 2014: 278). Rosenberg (2006) explains that according to this arrangement, the planned hydropower plant was removed and the storage capacity of the dam, which was about to start construction, decreased from $220 \mathrm{MCM}$, as envisioned in 1987, to $115 \mathrm{MCM}$ in 2001. On 9 February 2004, the inauguration of the construction work of the Wahda Dam finally took place (Rosenberg 2006: 28; Zawahri 2010: 137-138; Curtis 2006). It only became operational in 2006 and fully completed in 2009 (UN-ESCWA 2013: 211).

For several decades the Jordanian government had been pushing strongly for the construction of the Wahda Dam, which it envisioned as a partial solution to Jordan's water scarcity problem (interview 6 with a high-level Jordanian MWI official). However, the dam's maximum storage volume was reached in 2009/2010 at only 20 MCM - even though its maximum capacity is 110 MCM (UN-ESCWA 2013: 211). Since 2011, a slight increase in the flow to the Wahda Dam has been registered (Namrouqa 2012): a cumulative peak of about $60 \mathrm{MCM}$ was reached at the beginning of the political instability in Syria, according to high-level Jordanian officials from the MWI. They noted that this was driven by a decrease in farming activities due to unstable conditions and power cuts, which resulted in about 50\% decrease in irrigated agriculture (Müller et al. 2016). The decreased use of water for farming activities negatively affected the water release from the Syrian dams and resulted in more carry-over volumes of retained water in the Syrian dams (interviews 6, 7, and 8 with MWI officials). 
Through this outline, my aim is to show that in spite of the different agreements and arrangements that the Jordanian and Syrian governments signed, the implementation of these agreements was not without problems. This is particularly true for the Jordanian government, as exact amounts of water for Jordan are not specified in the current 1987 agreement. The hydropolitical controversy arose when the Wahda Dam was finally built and when it became obvious that the Jordanian access to water was definitely less than what the Jordanian authorities had expected.

In the following sections, I compare and contrast governmentally sanctioned, and thus dominant, Jordanian and Syrian hydropolitical discourses. An analysis of these varying discourses brings to the fore the types of solutions implied and opened.

\section{A Jordanian perspective: 'Syria keeps violating the agreement'}

This section unpacks Jordanian dominant and governmentally sanctioned hydropolitical discourses - in other words, the Jordanian shared way of understanding hydropolitical relations - generated out of the ambiguities following the 1987 bilateral agreement. My aim is to explore the policy options these discourses open up and the (im)possibilities of their implementation. ${ }^{7}$ The mainstream Jordanian hydropolitical discourse is composed of two themes: one that blames the Syrian government for not respecting the bilateral agreements, and another that blames population growth and neighbouring countries for causing water scarcity in Jordan. Through a discussion of these themes, this section will show that the contentions around the Yarmouk River are of political rather than technical nature. This hydropolitical discourse, I argue, reproduces a reality that drives towards supply-side solutions that include increasing the Jordanian share of the Yarmouk River through strengthening cooperation with the Syrian government and convincing the Syrians to respect the current bilateral agreement (signed in 1987).

In the first theme, the focus revolves around discontent with Syria's violations of the two main bilateral agreements, the 1953 and the 1987. This is evident in public statements repeated by Jordanian officials. For example, Haddadin, former President of the Jordan Valley Authority (1982-1987) and former Jordanian Minister of Water and Irrigation (MWI) (1997-1998) asserts that 'the Syrians have consistently violated the provisions of the 1953 Agreement' (Haddadin 2012: 280). He traces the tensions between the two countries to 1968, when the Syrian government started to build the Daraa Dam on the Zaydi tributary without Jordanian consent. Along the same lines, Mousa Jamani, another former Jordanian minister of the MWI, pointed out in a public interview in 2012 that 'the number of Syrian dams increased from 26 to 48, while around 3,500 wells were drilled to pump [ground]water from the river basin.' These activities were taking place without Jordanian consent (Namrouqa 2012). These complications were not about the practicalities of water sharing; rather, they were about honouring both the 1953 and renegotiated 1987 agreements (Kubursi et al. 2011: 8). To add to this, officials highlighted the problems caused for Jordan as a result of the 42 dams that were built in Syria on four tributaries feeding the Yarmouk River. As put by Zoubi, former Jordanian MWI Secretary General, 'Syria's continuous well drilling in the Yarmouk Basin negatively impacts the base flow in the

\footnotetext{
${ }^{7}$ I do not focus on the non-mainstream, emerging counter-discourses by NGOs and international organisations, but rather on the official Jordanian, governmentally sanctioned and dominant one. This is because, as shown by Hussein (2016: chapter 7), these non-mainstream ones do not influence the implementation of policies.
} 
river, reducing it by approximately 30 percent' (Zoubi 2014: 278). In Jamani's words, 'the solution to Yarmouk Basin water sharing is not technical, it is political' (Namrouqa 2012). The developments around the Wahda Dam, which the Jordanian government had been strongly backing, did not produce the results expected.

The second theme focuses on water scarcity and its perceived causes, mainly population growth (MWI 2009) caused by displacement and migration in the region (see Hussein 2016; e.g. interviews with governmental personnel 8, 14, 17, 18, 22, 25, and 42, with donors 28, 39, and 45, and with academics 3, 4, 7, 11). My interviewees saw the 'refugee problem' as the main factor for water scarcity, an issue that is emphasised in reports and articles. For example, Haddadin dedicates the first chapter of his book 'Water Resources in Jordan', co-authored with geologist Elias Salameh, to the population issue. As highlighted in Table 2, they argue that 'Jordan's population grew 11.5 times in 66 years, from 0.3 million in 1938 to 5.35 million in 2004 , because of the abrupt influx of population in the wake of the turbulence that has been affecting the Middle East' (Haddadin 2006: 24-25). It is interesting that this theme focuses on waves of migration from neighbouring countries when it overlooks other relevant factors, such as the natural fertility rate of Jordanians, among others, which also contributes to population grew, which is seen as one of the main causes of water scarcity. This omission further emphasises that this theme focuses and underlines the 'refugee problem'. Currently, the main focus is on the Syrian refugees' impact on Jordan's water resources. The MWI has published a report in 2013 entitled 'the Cost of Hosting Syrian Refugees on Water Sector of Jordan'. The report analyses both the short and long term impacts of the Syrian refugees on water resources and considers direct and indirect costs (MWI 2013: 19-22). Governmental personnel, academics, and the media have all cited this report as evidence that supports this theme. For example, the Jordan Times has also reproduced it in its reporting:

The deteriorating regional conditions and turmoil have led to waves of hundreds of thousands of refugees flowing into Jordan, pushing it over time from being one of the world's 10 water-poorest countries in the world, to the fourth and now the second, according to ranking by the United Nations, Ministry of Water and Irrigation Spokesperson Omar Salameh told The Jordan Times. [...]. The main challenge to the water sector, according to [the government coordinator for human rights report on challenges the water sector is facing], is the increasing demand for water due to the ongoing influx of Syria refugees into the country. (Namrouqa 2014)

Table 2: Demography of Jordan over time

\begin{tabular}{|r|l|l|}
\hline Year & Population of Jordan & Major political event \\
\hline 1922 & 225,000 & Emirate of Transjordan founded in 1921 \\
\hline 1947 & 473,200 & One year before the establishment of Israel \\
\hline 1952 & 586,200 & After the 1948-1949 war with Israel \\
\hline 1970 & $1,508,200$ & $\begin{array}{l}\text { Three years after the six days war with Israel, } \\
\text { and the Israeli occupied the East Jerusalem } \\
\text { and the West Bank. }\end{array}$ \\
\hline 1989 & $3,144,000$ & One year before the Iraq-Kuwait war \\
\hline 1993 & $3,993,000$ & Two years after the Iraq-Kuwait war \\
\hline
\end{tabular}




\begin{tabular}{|r|l|l|}
\hline 2002 & $5,098,000$ & One year before the war against Iraq \\
\hline 2004 & $5,350,000$ & One year after the war against Iraq \\
\hline 2010 & $6,113,000$ & One year before the Syrian crisis \\
\hline 2012 & $6,388,000$ & One year after the start of the Syrian crisis \\
\hline 2015 & $9,500,000$ & Three years after the start of the Syrian crisis \\
\hline
\end{tabular}

The Jordanian hydropolitical discourse presented above refines and redefines a reality of water scarcity in the country based on Syrian violations of the bilateral agreements and population growth. This discourse drives towards supply rather than demand-side solutions. Supply-side solutions aim at increasing water resources in the country, for instance through desalination or construction of new dams. The Jordanian government mainly backs such supply-side solutions, although it also adopts some demand-side solutions at the same time: for example, it adopts water tariff adjustments periodically, invests in improving water distribution efficiencies, especially in irrigation and municipal water systems, and in training of personnel. It also invests in upgrading management and measurement systems. This is reflected in the Jordanian water strategy which emphasizes claiming and increasing Jordanian rights to shared water resources, including the Yarmouk, as a priority to solve the water scarcity issue in the country (MWI 2009).

In spite of these solutions, the Jordanian government has not succeeded in strengthening transboundary water cooperation with the Syrian government and in claiming and increasing the Jordanian share rights on the Yarmouk basin. As noted by Hussein and Grandi (2017), the difficulty in bilateral cooperation is also due to the following political events that made it challenging - if not impossible - for the Jordanian authorities to reach an agreement with the Syrian counterpart. The first is the period of the Arab Cold War between 1957 and 1967. The second is the duration of the Iraq - Iran war in which Syria and Jordan supported Iran and Iraq respectively. The third is the war on Iraq in 1991 in which Syria sided with the USA but Jordan did not. The fourth is the boycott of Iraq to which Jordan was not enthusiastic. The fifth is the war on Iraq in 2003. Finally, the sixth is the civil war that started in 2011 and is still going on in Syria. Altogether, these events have challenged cooperation between the two countries.

\section{A Syrian perspective: Jordan's relationship with Israel, mismanagement, and climate change}

Jordanian hydropolitical discourses represent Jordan's water scarcity as being primarily a result of Syrian violations. In turn, Syrian hydropolitical discourses also create a shared understanding of hydropolitics and Jordan's water scarcity. The themes that constitute these discourses revolve partly around Jordan's perceived mismanagement of water and predominantly around Jordan's relationship with Israel. In interviews with Syrian informants, the 1994 Jordanian-Israeli agreement was cited as the main reason behind Jordan's need for more water from the Yarmouk. It was suggested that the water was being supplied to Israel rather than endorsing the fact that Jordan is a water scarce country. The Syrian diplomats I interviewed (interview 13 and 14) insisted that 'the Jordanian government is to blame for the water scarcity, as it has agreed to give up its own water resources to Israel.' One of the Syrian diplomats underlined that 'Jordan has signed the water part of the 1994 agreement 
without consultation with Damascus, and now they want more Yarmouk water [from Syria] to give it to Israel in line with the treaty they have signed' (interview 13). When I presented this Syrian hydropolitical discourse of Israeli dominance to a former Jordanian minister (interview 12), he expressed that 'this is nonsense.' He said that in 1992, in an Arab meeting to coordinate the political negotiations with Israel, Syria - represented by its foreign minister Farouk Al- Share - decreed that each Arab party should 'pull out the thorns in his hand by himself' - insisting that each Arab party to the bilateral negotiations should manage its own affairs.' For the former Jordanian minister, this clearly meant giving the green light for bilateral rather than regional negotiations and agreements with Israel. High-level Syrian diplomats believe that with the 1994 treaty the 'Jordanian government recognised and legitimised that Israel diverts a significant proportion of Jordan River water from Lake Tiberias through its National Water Carrier (NWC)' (interview 13). The 1994 treaty undermined 'the rights of all other riparian states - including Syria ${ }^{8}-$ on the Jordan River Basin' (ibid.).

Jordanian officials disagreed with the Syrian shared understanding of hydropolitics. For example, when I put the Syrian hydropolitical perspective to a Jordanian former minister of the MWI, the minister retorted, 'this is truly false because [the Jordanian government] insisted [during the 1994 negotiations] in writing that whatever the two sides [the Jordanian and Israeli governments] debate and negotiate does in no way prejudice the rights of the other riparians on the Jordan basin. No mention was made of the Upper Jordan from which Israel pumps water into the NWC' (interview 12). The NWC was built in 1964 and carries water to Israeli cities outside the Jordan River Basin. Overall, this Syrian hydropolitical discourse constructs a reality in which the blame is on the Jordanian government for its relation with Israel, implying that the solution lies in Jordan's reconsideration of its relationship with Israel.

Syrian officials also believed that Jordan mismanages its own water resources. One of the Syrian diplomats I interviewed explained his view:

Households in Syria are given water every day for around four hours, and for this reason Syrians do not waste water. We have been doing it since 2003 in the Damascus area, and it has been a success [...]. Instead, water in Jordan is provided to households only once a week for up to 24 hours. This results in people eagerly awaiting the 'water day' and wasting the water by washing cars, gardening, and other activities on that day. (interview 14)

More than one Syrian diplomat emphasised to me that Syrians did not feel or perceive water scarcity to be a problem as much as people in Jordan. They maintained that while there are persisting water resource management issues in some regions and parts of the country, overall, there is no water scarcity at a more national level in Syria. These Syrian hydropolitical discourses, therefore, redefine a reality in which the Jordanian state is accountable for the mismanagement of water resources and for creating water scarcity in Jordan.

In my interviews with Syrian officials, other themes emerged as my interlocutors discussed water scarcity. For instance, several interviewees commented on the

\footnotetext{
${ }^{8}$ This is because the Yarmouk River is part of the Jordan River Basin.
} 
decreased flow of the Yarmouk River. They related this decrease to Syria's entitlement for a larger portion of the water, and to climate change. According to one senior Syrian diplomat (interview 15), given that four out of five tributaries of the Yarmouk River are in Syria, $80 \%$ of the Yarmouk River is 'Syrian water,' because 'this is what international law says.' This interviewee seemed to be suggesting that, based on his understanding of international law, Syria should get more water proportionally. What follows from this logic is that Syria is not violating the 1987 agreement as, according to international law, Jordan is entitled to $20 \%$ of the Yarmouk River. However, no exact references to international law were provided by the high-level Syrian diplomats interviewed (interviews 13 and 15), who also asserted Syria's entitlement to the water resources of the Yarmouk basin. In fact, this view does not correspond to specific principles of international water law.

The other theme that also emerged from the interviews sees climate change as responsible for reducing the flow of the Yarmouk River into the Wahda Dam and for exacerbating water scarcity in both Syria and in Jordan. The Syrian diplomats emphasised the negative impacts of climate change, particularly in terms of reducing precipitations and contributing to increasing water scarcity in several regions of the country. This is a dominant theme in Syria, and one that is reproduced through the media as well as within academic discourse. For instance, the Syrian academics Skaf and Mathbout (2010) have highlighted how climate change has been contributing to the increased numbers of droughts in the past decade. For them, 'there is an increasing tendency in annual and seasonal drought intensity in all regions corresponding with an increasing dry days number in rainy season' (Skaf and Mathbout 2010: 112). This theme blames water scarcity and the decreased flow of the Yarmouk River on nature and the environment, specifically climate change and reduced precipitation.

\section{Discourses, interests, and power asymmetries as explanatory factors}

The hydropolitical discourses that emerge from the interviews I conducted with Syrian and Jordanian officials shed light on the different realities of their assessment of water scarcity. Yet, there are some converging issues that are worth highlighting for the purpose of the following discussion. Particularly, two issues are worth underlining. Firstly, it appears that both Syria and Jordan need and use water to rally internal support of their citizens. Secondly, both Syrian and Jordanian hydropolitical discourses reproduce a reality in which they externalise the problem of water scarcity and of the reduced amount of water reaching the Wahda Dam. The discussion below shows the interconnections of these two. I suggest that an analysis of the hydropolitical dynamics in the basin may explain why Jordan has not been successful in strengthening bilateral cooperation over water.

Rallying political support through providing water access seems to be a common feature for both governments. For the Jordanian government the main objectives are to increase water resources, to maintain the current uses in Jordan, and to meet the growing water demand. Maintaining current water uses is particularly important because of the political support the government receives from farmers and rural communities, who are the highest consumers of water resources, and whose water is highly subsidised by the government (Yorke 2016; Yorke 2013; Hussein 2016). In similar ways, scholars of Syria argue that the Syrian government has historically supported unsustainable farming to ensure farmers' political backing and food self- 
sufficiency (Azmeh 2016). 'The Bashar al-Assad regime traditionally provided large subsidies for the production of water-intensive crops, such as wheat and cotton. Most of Syrian irrigated agriculture is in need of modernization, still relying on highly inefficient flood irrigation' (Gleick 2014: 334). It is not surprising therefore that almost $90 \%$ of the water resources in Syria are used by the agricultural sector (Salman and Mualla 2008). Some even argue that the Syrian agricultural sector was based on over-exploitation and subsidies rather than on economic or environmental constraints (de Châtel 2014: 88).

Syria's water scarcity is a consequence of the ruling Ba 'th party's continuous promotion of water-intensive agriculture [...] motivated in part by a desire for food self-sufficiency and growth through an expansion in irrigated agriculture [and to the] roots of the Bath party and the influential Peasants Union. (Barnes 2009: 510)

This support to farmers is also visible when it comes to the permits to dig wells, which were very easily obtainable in the past decades; as one Syrian official stated: 'they'll dig whether or not we give them approval. At least this way [by approving requests] we know where some of the new wells are' (ARK 2016: 2)

In line with the goal of the two governments to rally internal support of citizens, both Syria and Jordan externalise the problem of water through the construction of discourses through which they redefine their reality in the 'battle for truth.' As we have seen above, for the Syrian government, the decrease of the Yarmouk flow is due to the political problem of Jordan's relationship with Israel on the one hand, and to the reduction in precipitation upstream due to climate change, on the other. As such, the Syrian hydropolitical discourses place the blame on the Jordanian government and on natural factors, externalising responsibility towards actors outside of the Syrian government or country. The Jordanian hydropolitical discourse also locates the causes of water scarcity outside of Jordan's government and blame the Syrian government for not respecting the bilateral agreements with Jordan and over-exploiting water resources upstream. These contested hydropolitical discourses are key to understand and unfold the Jordanian-Syrian water controversy over the Yarmouk River.

The realities constructed by the competing Syrian and Jordanian hydropolitical discourses open different solutions. For the Syrians, the solution appears to be technical, in research studies and reports that find new ways in dealing with climate change. For the Jordanians, on the other hand, the main solution is political and seems to lie in having the bilateral agreement respected by both sides. While the Syrian government aims to maintain the status quo, the Jordanian government strives to increase its share by appealing to the bilateral agreements. However, Jordan has failed in achieving its aim. In line with the framework of hydro-hegemony, this article pays attention to the geopolitical considerations that lead to specific power dynamics between these two countries.

In exploring the reasons why the Jordanian government was unable to stop Syrian violations, a former Jordanian minister of the MWI (interview 12) cited interrelated reasons: the fact that the Syrian state is in the upstream region of the Yarmouk Basin and the Jordanian one downstream, that Jordan has a population of 5 million people while Syria has 25 million people and that the military in Syria has been historically 
stronger than Jordan's military abilities. Moreover, he argued that for the Jordanian government, the transit trade route through Syria was strategic. Put simply, the former minister's point was that Jordan could not do much about the violations of the agreement because the Jordanian government was less powerful than the Syrian one. Moreover, Syria's perception of Jordan's allegiances that fall outside of its geopolitical interests (given Jordan's relationship with the USA and Israel) has fed into the conflictive relationship over water cooperation between the two countries. ${ }^{9}$

There are other reasons why Jordan has not pressed for legal action against Syria's violations. Interviews with high-level officials from the Jordanian MWI and Ministry of Foreign Affairs (MFA) indicate that water was often not the top priority in overall bilateral relations for the Jordanian government (interviews 9, 10, 11, and 12). While at a national level, water remains a top priority in Jordan, in terms of bilateral relations with the Syrian government, other inter-sectorial relations take priority. According to a former Jordanian ambassador, the Jordanian government could not do much because water 'was not on top of the Jordanian priority list; water was a topic that was given to the engineers. The priorities of our foreign policies towards Syria were trade, the peace process, and political [issues]' (interview 9 with a former Jordanian ambassador). For a high-level official of the MWI, the consolidated and important interests in other sectors, in particular trade, are the main reason why the Jordanian government never undertook any action against the Syrian violations apart from the statements they released to condemn them (interview 8).

Although the Jordanian hydropolitical discourse constructs a reality that drives towards increasing its share and development of the Yarmouk River (Hussein 2016), as is stated in the Jordanian national water strategy (MWI 2009), the Jordanian government has not achieved its aims in terms of TWG in the Jordanian-Syrian hydropolitical relations. As summarised by a former Jordanian ambassador (interview 9), 'Syria has been a powerful player in the region ... and Jordan has prioritised its interest in other sectors.' While dominant discourses matter, especially at the national level, when it comes to TWG, discourses are only one aspect of power that determine change and policies' implementation, as shown by the Framework of HydroHegemony. In other words, the discourse of water scarcity is one of many determinants of the hydropolitical relations and of TWG. Consequently, the Jordanian government has failed in its solutions to counter the hydropolitical status quo and to transform current configurations and water allocations in the Yarmouk Basin.

To conclude, we may consider Syria to be the hydro-hegemon and Jordan to be the non-hydro-hegemon in overall bilateral relations. While the non-hydro-hegemonic riparian state - Jordan - deploys discursive power to attempt to challenge the disadvantageous hydropolitical relations and the status quo, this Jordanian attempt of counter-hegemony fails because of considerations of power asymmetries and of overall bilateral relations (Hussein 2016).

\section{References}

\footnotetext{
${ }^{9}$ From a geopolitical perspective, the Syrian government perceives the Jordanian government to be working outside of Syria's geopolitical alliances. In fact, in the past decades, the Jordanian government has been a close ally of the US and signed a peace agreement with Israel, while the Syrian government has been closer to the Russian and Iranian governments. This geopolitical division has fed into the conflictive relationship over water cooperation between the two countries.
} 
ARK 2016. All is not well: The urgency of water governance in southern Syria. ARK Special Report, April 2016.

AZMEH, S. 2016. Syria's Passage to Conflict: The End of the "Developmental Rentier Fix" and the Consolidation of New Elite Rule. Politics \& Society, 44, 499-523.

BARNES, J. 2009. Managing the Waters of Ba th Country: The Politics of Water Scarcity in Syria. Geopolitics, 14, 510-530.

CURTIS, R. 2006. The Odd Couple: Ending The Jordanian-Syrian "Cold War". The Middle East Journal, 60, 33-56.

DE CHÂTEL, F. 2014. Leaving the Land: The Impact of Long-Term Water Mismanagement in Syria. Water Scarcity, Security and Democracy: A Mediterranean Mosaic.

DRYZEK, J. S. 1997. The politics of the earth: Environmental discourses, Oxford University Press.

ETANAFILES 2015. The Yarmouk Basin between conflict and development.

FAO 2009. Irrigation in the Middle East region in figures: AQUASTAT Survey - 2008

FOUCAULT, M. 1980. Truth and Power. In C. Gordon (ed.): Power/knowledge. Selected Interviews \& Other Writings by Michel Foucault, 1972-1977, Brighton: Havester, pp. $109-133$.

FOUCAULT, M. 1991. Discipline and Punish: the birth of a prison. London, Penguin.

FOUCAULT, M. 1998. The History of Sexuality: The Will to Knowledge, London, Penguin.

GAVENTA, J. 2003. Power after Lukes: an overview of theories of power since Lukes and their application to development. Brighton: Participation Group, Institute of Development Studies

GLEICK, P. H. 2014. Water, drought, climate change, and conflict in Syria. Weather, Climate, and Society, 6, 331-340.

HADDADIN, M. 2009. Cooperation and lack thereof on management of the Yarmouk River. Water International, 34, 420-431.

HADDADIN, M. J. 2006. Water resources in Jordan: evolving policies for development, the environment, and conflict resolution, Resources for the Future.

HADDADIN, M. J. 2012. Diplomacy on the Jordan: International conflict and negotiated resolution, Springer Science \& Business Media.

HAJER, M. A. 1995. The politics of environmental discourse: ecological modernization and the policy process, Oxford University Press Oxford.

HAYWARD, C.R. 1998. De-Facing Power, Polity 31(1).

HOF, F. C. 1998. Dividing the Yarmouk's waters: Jordan's treaties with Syria and Israel. Water Policy, 1, 81-94.

HUSSEIN, H. 2016. An analysis of the discourse of water scarcity and hydropolitical dynamics in the case of Jordan. PhD Thesis, University of East Anglia.

HUSSEIN, H. \& GRANDI, M. 2015. Contexts Matter: A Hydropolitical Analysis of Blue Nile and Yarmouk River Basins. Social Water Studies in the Arab Region, 159.

HUSSEIN, H. \& GRANDI, M. 2017. Dynamic political contexts and power asymmetries: the cases of the Blue Nile and the Yarmouk Rivers International Environmental Agreements: Politics, Law and Economics.

HUSSEIN, H. 2017a. Politics of the Dead Sea Canal: a Historical Review of the Evolving Discourses, Interests, and Plans. Water International, Vol. 42, issue 5. 10.1080/02508060.2017.1344817

HUSSEIN, H. 2017b. A critique of water scarcity discourses in educational policy and textbooks in Jordan, The Journal of Environmental Education.

IFC 2012. Socio-Economic Impact of IFC Financing in Jordan - An Assessment of Employment and Value-added -.

KUBURSI, A., GROVER, V., DARWISH, A. R. \& DEUTSCH, E. Water scarcity in Jordan: Economic instruments, issues and options. Economic Research Forum Working Paper Series, 2011. 
LEACH, M. \& MEARNS, R. 1996. The Lie of the Land: challenging received wisdom on the African environment, James Currey Ltd.

LUKES, S. 1974. Power: A radical view, London Macmillan.

MÜLLER, M. F., YOON, J., GORELICK, S. M., AVISSE, N. \& TILMANT, A. 2016. Impact of the Syrian refugee crisis on land use and transboundary freshwater resources. Proceedings of the National Academy of Sciences, 113, 14932-14937.

MWI 2009. Water for Life. Jordan's Water Strategy 2008-2022. Amman: Ministry of Water and Irrigation.

MWI 2011. National water master plan. Amman: Ministry of Water and Irrigation.

NAMROUQA, H. 2012. 'Yarmouk water sharing violations require political solution' The Jordan Times, 28 April 2012.

NAMROUQA, H. (2014). 'Jordan world's second water-poorest country.' The Jordan Times 22 October 2014.

NORTCLIFF, S., BLACK, E. \& POTTER, R. 2011. Current water demands and future strategies under changing climatic conditions. Water, Life and Civilisation: Climate, Environment and Society in the Jordan Valley, 403.

ROSENBERG, D. 2006. The Yarmouk River Agreements: Jordan-Syrian Transboundary Water Management, 1953-2004. The Arab World Geographer, 9, 23-39.

SALMAN, M. \& MUALLA, W. 2003 The utilization of water resources for agriculture in Syria: Analysis of current situation and future challenges. Erice International Seminars on Planetary Emergencies, 18-26.

SALMAN, M. \& MUALLA, W. 2008. Water demand management in Syria: Centralized and decentralized views. Water Policy, 10, 549-562.

SKAF, M. \& MATHBOUT, S. 2010. Drought changes over last five decades in Syria. Economics of drought and drought preparedness in a climate change context, 107112.

UN-ESCWA, B. 2013. Inventory of Shared Water Resources in Western asia. Beirut.

YORKE, V. 2013. Politics matter: Jordan's path to water security lies through political reforms and regional cooperation. NCCR Trade Regulation, Working Paper 2013/19.

YORKE, V. 2016. Jordan's shadow state and water management: prospects for water security will depend on politics and regional cooperation. Society-WaterTechnology. Springer.

ZAWAHRI, N. A. 2010. Governing the Jordan River system: History, challenges, and outlook. Journal of Transboundary Water Resources, 1, 127-147.

ZEITOUN, M. \& WARNER, J. 2006. Hydro-hegemony-a framework for analysis of transboundary water conflicts. Water policy, 8, 435-460.

ZOUBI, M. 2014. Benefit sharing, water and cooperation: the Jordanian case. Turkish Review, 4, 276. 